\title{
RESPONSE OF BEETLE COMMUNITIES FIVE YEARS AFTER WILDFIRE IN MEDITERRANEAN FOREST ECOSYSTEMS
}

\author{
(*) Department of Agricultural and Environmental Sciences, University of Bari “A. Moro”, Bari, Italy. \\ (**) Department of Soil, Plant and Food Sciences, University of Bari “Aldo Moro”, Bari, Italy. \\ ${ }^{\dagger}$ ) Corresponding author: e-mail: mario.elia@uniba.it
}

\begin{abstract}
Elia M., Lafortezza R., Tarasco E., Sanesi G. - Response of beetle communities five years after wildfire in Mediterranean forest ecosystems.

Wildfires are one of the most important drivers of forest composition and biodiversity in the Mediterranean Basin. Many studies have demonstrated that fires can affect insect diversity by altering the functional traits of species groups. We examined the 5-year response of beetles to wildfires by assessing patterns of community composition across a gradient from forest interior to forest edge to burnt forest area in Southern Italy. Our objective was to characterize the relationship between distance from the forest edge and occurrence of beetle taxonomic assemblages. We analyzed the composition, similarity, and dominance of ground beetle communities in randomly selected plots located along the forest-to-burned-area gradient. We found a negative relationship between community similarity and distance from the forest edge; moreover, the composition of species assemblages (within each family) became increasingly similar with proximity to the forest edge. As the distance from the forest edge into the burned area became greater the dominance of few species increased, and species composition shifted toward habitat generalists. The results partially support the notion that the differences in beetle communities probably are driven by habitat changes caused by fires, especially for those taxa with many specialist species in feeding and oviposition habitats. Understanding the biological effects of wildfires is necessary prior to design management strategies and policies for counteracting the loss of biodiversity at the global, regional and national levels.
\end{abstract}

KEY WoRDS: Wildfire, Beetles community, Similarity index, Mediterranean forests, Biodiversity.

\section{INTRODUCTION}

Wildfires are one of the main factors influencing the composition and spatial turnover of insect communities, which represent an important pool of biodiversity in forest ecosystems and landscapes (HollidaY, 1991; VillaCASTILlO and WAGNER, 2002; RAINIO and NiMELÄ, 2004). The insect biodiversity can be directly and indirectly affected by wildfire. Direct effects are due to the heat and smoke generated by the fire. Many insects may be able to escape fires through flight, but non-flying insects need to rely on other strategies to survive, including exploiting micro-refugia such as bush clumps, rocks and marshy areas (Uys et al., 2006), burrows (DIPPENAAR-SCHOEMAN, 2002) or moving beneath the soil surface (VILLANI et al., 1999). Indirect effects can be ascribed to the alteration of ecosystem structure, especially vegetation (ELIA et al., 2016), soil and litter composition (WHELAN, 1995; Pickering, 1997; Swengel, 2001; Buddle et al., 2006). The consequence is that both species richness and abundance were negatively affected by fire.

A number of studies have focused on the effects of wildfires on different insect taxa, especially ground beetles (LARSEN and Williams, 1999; GANDHI et al., 2001; SAINTGERMAIN et al., 2005; JoHANSSON et al., 2011; Elia et al., 2012). In their study on Mediterranean pine forests, NUNES et al. (2006) found that the abundance of ground beetles tends to decrease over a two-year time period after the fire. EliA et al. (2012) confirmed these short-term effects of fires on ground beetle communities. On the other hand, other studies showed a contrasting pattern of increasing abundance during the post-fire period (see: WARREN et al.,
1987; ReED, 1997; GARCIA-TEJero et, al, 2013). Fireinduced effects on beetles are therefore difficult to generalize because diverse communities may respond differently during the post-fire period in relation to the resilience of the community (i.e., species turnover) and the rate of changing vegetation conditions after fires (TEASDALE et al., 2013; REINHARDT et al., 2006; CAMPBELL et al., 2007; EliA at al., 2015). Although there is a body of literature focusing on the cause-and-effect relationship between wildfires and beetle communities in the short-term period (up two years after fire), only a few studies have investigated this relationship over a longer period of time after a fire.

In this paper, we investigated the response of beetle communities five years after fire by assessing patterns of community composition across a gradient from the forest interior to the burnt forest area. To this end, we analyzed the composition of beetle communities in terms of similarity and dominance in random plots located inside the forest (control plots) and over the burnt area at different distances from the nearest forest edge (burnt forest plots).

We hypothesized that the community composition of beetles within control plots located inside the forest area is representative of the community that would have existed in the absence of wildfire. This community composition should be more similar between control sites than between a control site and a forest location that has been affected by a wildfire (burnt forest plot). To test our hypothesis, we assessed the similarity of beetle species in a Mediterranean forest ecosystem five years after a fire. We used the distance between burnt forest plots and control plots to explain the spatial distribution of the beetle community across the gradient: forest interior - forest edge - burnt area (see Table 1). In a 
Table 1 - The gradient used to explain the spatial distribution of beetle community in the study area.

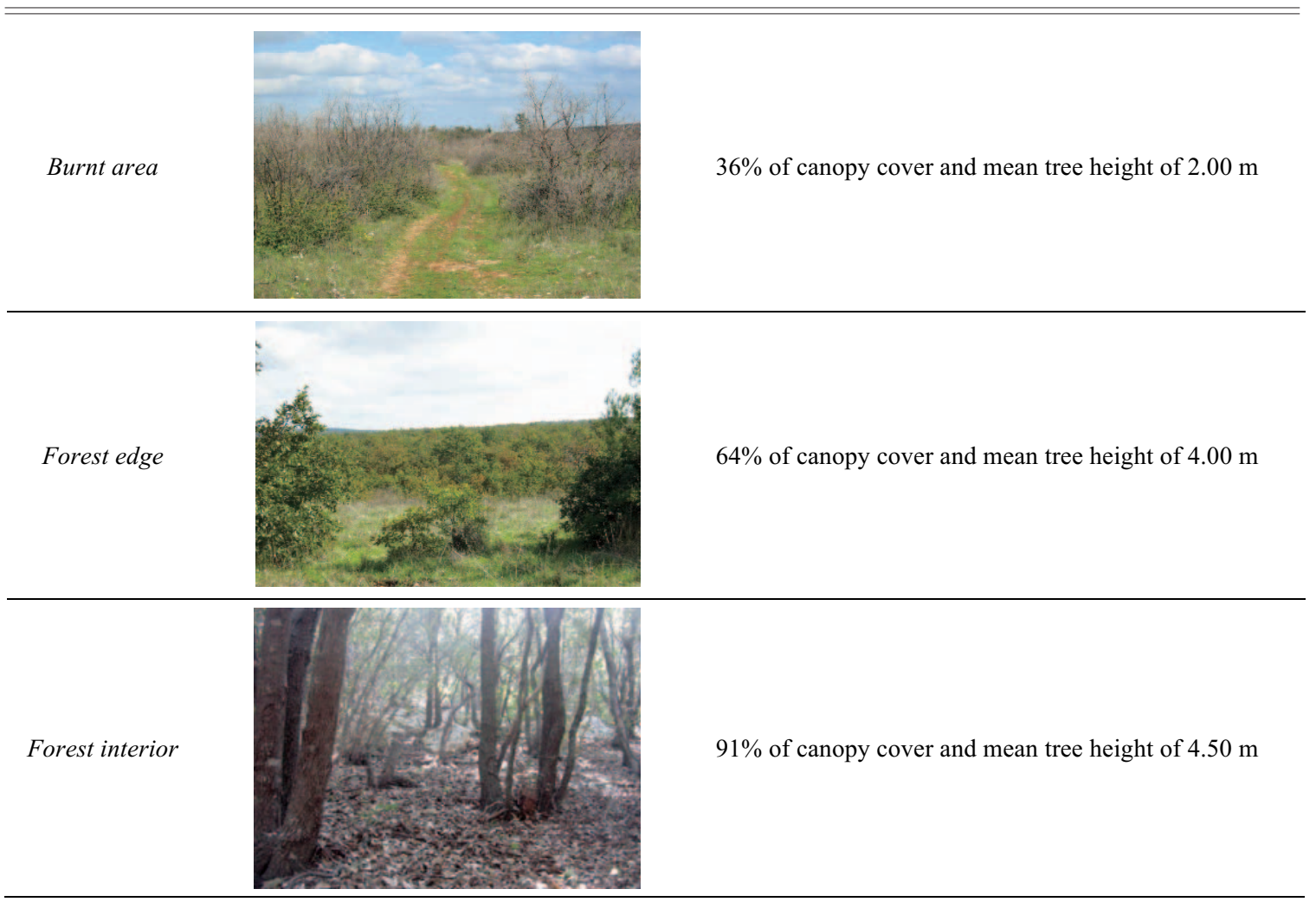

subsequent step, we analyzed the community of beetles within burnt forest plots in terms of dominance to test the hypothesis that as the distance from the nearest forest edge increases, only a few species become dominant, whereas a majority of species exist in moderate or low abundance (subordinate or rare species).

We focused our analysis on beetles because they have been extensively studied as indicators of environmental conditions and ecosystem disturbances, including wildfires (LARSEN, 1999; MoretTi et al., 2004; KoIVUla and Spence, 2006; PRYKE et al., 2012). In this perspective, the dynamics of the beetle community through space and time could provide insights into the rates of changing vegetation conditions after fire (HolLIDAY, 1991; VILLA-CASTILLO and WAGNER, 2002; ELIA et al., 2015).

The identification of the beetle communities that are most sensitive to wildfires plays a critical role in terms of postfire management and can be used to provide interpretive results. These outcomes may be applied to post-fire management strategies aimed at restoring forest ecosystems and species diversity (LAFORTEZZA et al., 2015).

\section{MATERIALS AND METHODS}

\section{STUDY SITE}

Field data on beetle communities were collected in a forest area covering ca. 600 hectares in the region of Apulia, Southern Italy $\left(40^{\circ} 55^{\prime} 43.63^{\prime \prime} \mathrm{N}\right.$; $16^{\circ} 36^{\prime} 52.05^{\prime}$ E) (Fig. I. During early July 2008, this area experienced a crown-fire ignited by farmers. The fire affected an area of ca. 260 hectares $(40 \%$ of the total forestand caused a severe reduction of the canopy tree cover (around 95\% of tree mortality). The woodland of this area is mainly represented by Quercus pubescens Willd. and $Q$. coccifera L., with large open spaces covered by herbs and seedlings such as:
Ruscus aculeatus (L.), Myrtus communis (L.), Calicotome villosa (Poir.), Cistus incanus (L.), C. monpeliensis (L.), C. salvifolius (L.), Spartium junceum (L.), and Euophorbia dendroides (L.). The understory vegetation includes Pistacia lentiscus (L.), P. terebinthus (L.), Rosa canina (L.), Crataegus monogyna (Jacq.), Phillyrea spp, Rhamnus alaternus (L.), Erica arborea (L.), Rubus ulmifolius (Schott.), Smilax aspera (L.) and Arbutus unedo (L.).

The variations in the structure and composition of this forest are mainly determined by human-induced impacts. These variations include coppicing and firewood collection, which have taken place over the past 20 years, overgrazing, and fires (LAFORTEZZA et al., 2013). Table 1 shows the gradient form forest interior to burnt area used to explain the spatial distribution of the beetle community.

\section{BEETLE TRAPPING}

We sampled the beetle communities in our area by randomly placing three pit-fall traps inside the forest (control plots) and six traps in the burnt area at various distances from the nearest forest edge (burnt forest plots) (Fig. I). These standard pit-fall traps consisted of an outer and inner cup (9-cm diameter). They were buried in the ground with the rim at surface level and baited with vinegar to attract and preserve falling insects and subsequently covered with a sloped stone to protect them from rain and animal disturbance. The traps were kept active in the period lasting from May to July 2013 and emptied at ca.10-day intervals. All specimens collected were placed in a plastic container filled with $70 \%$ ethyl alcohol and examined in a laboratory for species identification.

\section{DATA ANALYSIS}

To test our first hypothesis, we assessed the similarity of community composition (i.e., spatial turnover) across a 

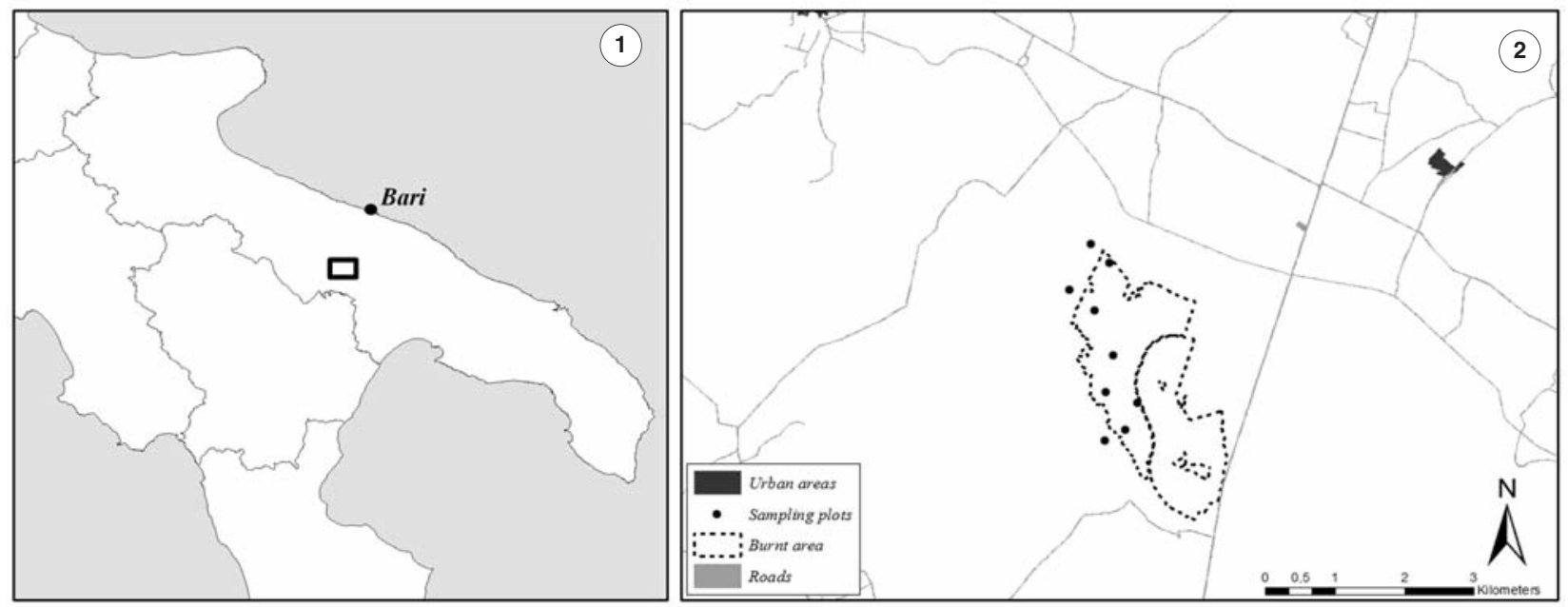

Fig. I - Location of the study area: 1) Apulia Region in Southern Italy; 2) boundary and location of the forest area affected by a fire in August 2008 (dashed line).

gradient from the forest interior to the burnt forest area in our study site.

For the purpose, we used the Bray-Curtis index (BC) one of the most common measures of community similarity (MAGURRAN, 2004):

$$
B C=1-\frac{\sum\left|Y_{i j}-Y_{i k}\right|}{\sum Y_{i j}+Y_{i k}}
$$

where $Y_{\mathrm{ij}}$ is the abundance of species $i$ in site $j, Y_{\mathrm{ik}}$ is the abundance of species $i$ in site $k$, and the summation is all species found at the two sites. The $\mathrm{BC}$ values range from 0 (no species in common) to 1 (identical abundance of all species) (LAFORTEZZA et al., 2010). We calculated $B C$ for each plot located in the burnt forest area (burnt forest plots) and the nearest control plot of similar altitude. We corrected the similarity value for any confounding effects of spatial autocorrelation and then used regression models to relate community similarity values to measures of distance from the nearest forest edge $(D)$. We calculated similarity values by: (1) considering the entire community of beetles collected during the survey period; and (2) grouping species according to family.

As a subsequent step, we focused only on the data collected in burnt forest plots and used a k-dominance analysis to assess the dominance distribution of individuals among species of beetles. The number of individuals of each species was sorted in descending order and the proportion of the total number of individuals for each species was plotted on a percentage scale against the species rank. The shape of the kdominance plot provides an indication of the dominance (or evenness) of a given species assemblage. For example, steep lines indicate assemblages with a high dominance, whereas shallower slopes characterize assemblages with low species dominance (i.e., higher level of evenness) (SiLva et al., 2014). A k-dominance analysis displays the cumulative proportion of abundance against the log species rank.

\section{RESULTS}

A total of 5326 specimens belonging to 15 families and 64 species were collected during the survey period (Table 2). Twenty-two species of Carabidae, 8 of Niti- dulidae, 7 of Staphylinidae, 5 of Tenebrionidae, 4 of Elateridae and Cerambycidae, 3 of Curculionidae, and 2 of Cetoniidae were trapped. We found only one species of Scydmaenidae, Lagridae, Dytiscidae, Lucanidae, Cantharidae, and Oedemeridae. The most abundant family was Nitidulidae $(85.2 \%$ ), followed by Carabidae (up to $6 \%$ ), Staphylinidae (5.1\%) and so forth. Within these families the most abundant species were Epuraea aestiva, Carabus coriaceus and Stenus sp., respectively.

As previously mentioned, we calculated an index of community similarity (BC) to assess differences in the community composition of beetles across the gradient from the forest edge to the burnt forest area (Fig. II). When considering the entire Coleoptera community, $B C$ ranged between 0.78 and 0.50 ; in other words, five years after the fire, the community composition of beetles in the plots located near the forest edge was $78 \%$ similar to the one in the absence of wildfire. Conversely, the community composition of beetles in the burnt forest locations was only $50 \%$ similar to the one observed in the control plots. The same pattern occurred when different beetle species were grouped according to taxa (Fig. II).

To further explore these patterns of variation, a number of regression models were developed to explain community similarity (BC) as a function of distance from the nearest forest edge $(D)$. The results are listed in Table 3. All regression models showed a negative relationship between community similarity and distance from the forest edge, with an explanatory power $\left(r^{2}\right)$ ranging between 0.57 and 0.81 . These results suggest that, in general, Coleoptera were negatively still affected by wildfire 5 years after the event. However, our regression models show a different slope, which can be seen as an indicator of spatial turnover of the beetle community. For example, the slope of the model describing community similarity in Nitidulidae appears significantly different (less steep) from that for Cerambycidae or Tenebrionidae. This suggests that the spatial turnover in Nitidulidae is less affected by wildfire than it is in other taxa of specialist species (SANTOS et al., 2014).

To assess the dominance of species assemblage in our study area, we grouped species abundance data according to three classes of distance from the nearest forest edge: 0-120 $\mathrm{m} ; 120-240 \mathrm{~m}$; and $>240 \mathrm{~m}$. The dominance distribution of individuals among species across the landscape is illustrated in Fig. III. The k-dominance plot shows that as the distance 
Table 2 - Number of beetle specimens collected during the survey period.

\begin{tabular}{|c|c|c|c|c|c|}
\hline Coleoptera & Species & Abundance & \multirow{2}{*}{ Dytiscidae } & & 2 \\
\hline \multirow[t]{2}{*}{ Cantharidae } & & 1 & & Colymbetes fuscus L. & 2 \\
\hline & Cantharis livida L. & 1 & \multirow[t]{2}{*}{ Elateridae } & & 51 \\
\hline \multirow[t]{23}{*}{ Carabidae } & & 316 & & Agriotes aterrimus L. & 44 \\
\hline & Abax ater Vill. & 33 & \multirow{6}{*}{ Lucanidae } & Elater ferrugineus L. & 2 \\
\hline & Amara fulva Müller & 1 & & Lacon punctatus Herbst & 4 \\
\hline & A. plebeja Gyll. & 2 & & Melanotus villosus & 1 \\
\hline & Brachinus crepitans L. & 4 & & Fourcroy & 1 \\
\hline & Calathus cinctus Mots. & 55 & & & 2 \\
\hline & C. fuscipes $\mathrm{G}$. & 4 & & Dorcus parallelepipedus L. & 2 \\
\hline & Calosoma sycophanta L. & 8 & Nitidulidae & Carpophilus dimidatus & 4539 \\
\hline & Carabus coriaceus L. & 116 & & $\begin{array}{l}\text { Fabr. } \\
\text { Farpopnims aimialus }\end{array}$ & 615 \\
\hline & C. glabratus Payk. & 4 & & C. marginellus Mots. & 603 \\
\hline & C. intricatus L. & 7 & & Epuraea aestiva L. & 701 \\
\hline & C. violaceus $\mathrm{L}$. & 16 & & E. pallescens Stephens & 650 \\
\hline & Cychrus caraboides L. & 7 & & E. unicolor Olivier & 648 \\
\hline & C. italicus Bon. & 2 & & Pocadius ferrugineus Fabr. & 602 \\
\hline & C. rostratus $\mathrm{L}$. & 2 & & Soronia grisea L. & 168 \\
\hline & Harpalus rufipes De Geer & 1 & & Urophorus humeralis Fabr. & 552 \\
\hline & H. luteicornis Dufts & 7 & \multirow[t]{2}{*}{ Oedemeridae } & & 1 \\
\hline & Leistus ferrugineus L. & 1 & & Oedemra flavipes Fabr. & 1 \\
\hline & L. spinibarbis Fabr. & 27 & \multirow[t]{2}{*}{ Scydmaenidae } & & 9 \\
\hline & Nebria brevicollis Fabr. & 1 & & Mastigus ruficornis Mots. & 9 \\
\hline & Pterostichus melas Creut. & 7 & \multirow[t]{3}{*}{ Silphidae } & & 2 \\
\hline & P. nigrita Payk. & 9 & & Phosphuga atrata L. & 1 \\
\hline & Zabrus tenebrioides G. & 2 & & Silpha carinata Herbst & 1 \\
\hline \multirow[t]{5}{*}{ Cerambycidae } & & 20 & \multirow[t]{5}{*}{ Staphylinidae } & & 271 \\
\hline & Cerambyx cerdo L. & 15 & & Astrapaeus ulmi Rossi & 4 \\
\hline & Clytus arietis L. & 2 & & $\begin{array}{l}\text { Staphylinus caesareus } \\
\text { Ceder }\end{array}$ & 1 \\
\hline & Purpuricenus kaehleri L. & 2 & & S. olens Müller & 64 \\
\hline & Ropalopus clavipes Fabr. & 1 & & Stenus sp. & 140 \\
\hline \multirow[t]{3}{*}{ Cetoniidae } & & 15 & \multirow{10}{*}{ Tenebrionidae } & Tachyporus hypnorum Fabr. & 7 \\
\hline & Cetonia aurata L. & 7 & & Tachinus laticollis Graven- & 37 \\
\hline & Potosia cuprea Fabr. & 8 & & horst & 26 \\
\hline \multirow[t]{3}{*}{ Curculionidae } & & 4 & & Blaps gibba Lap. & $\begin{array}{c}20 \\
5\end{array}$ \\
\hline & Pachytychius hordei Brullé & 1 & & B. mucronata Latr. & $\begin{array}{l}5 \\
4\end{array}$ \\
\hline & Pissodes notatus Fabr. & 3 & & Pedinus helopioides Ahrens & $\begin{array}{l}4 \\
5\end{array}$ \\
\hline \multirow[t]{4}{*}{ Dermestidae } & & 67 & & $\begin{array}{l}\text { Peatnus neloplolaes Anrens } \\
\text { Tentyria laevigata Steven }\end{array}$ & $\begin{array}{l}5 \\
3\end{array}$ \\
\hline & Attagenus unicolor Brahm & 62 & & $\begin{array}{l}\text { Ientyrla laevigata Steven } \\
\text { Tenebrio molitor L }\end{array}$ & $\begin{array}{l}3 \\
5\end{array}$ \\
\hline & Dermestes laniarius Illiger & 2 & & Ienebrlo molitor L. & $\begin{array}{l}5 \\
4\end{array}$ \\
\hline & D. maculatus De Geer & 3 & & Lagria hirta L. & 4 \\
\hline
\end{tabular}

from the forest edge increases, the dominance of some species increases. The k-dominance curves associated with the distance classes " 1 " $(0-120 \mathrm{~m})$ and " 2 " (120-240 m) appear rather similar in terms of shape and steepness; indeed, species abundance in these two distance classes is almost the same: 35 and 36 species, respectively (see Table 4). The k-dominance curve became steeper in distance class " 3 " ( $>240 \mathrm{~m})$. In this case the number of species decreased to 31 . The number of specimens increased across the gradient from the forest edge to the burnt forest area (from 1035 to 1170), while the number of families appears rather stable (ca. 11 to 12) (Table 4).

Our results suggest that species assemblage over the three distance locations is largely dominated by Nitidulidae, likely owing to the fact that these species are strongly generalist (ARbogast, 2009). On the other hand, the number of species and relative abundance of Carabidae tend to decrease as the distance from the forest edge increases. We found 12 species in distance classes " 1 " (0-120 m) and "2" (120-240 m) and 8 species in class " 3 " ( $>240 \mathrm{~m})$. For example, in our study area Carabus coriaceus was the most abundant species of the Carabidae taxon; such abundance decreased significantly as the distance from the forest edge decreased. In fact, we found 41 specimens in distance class " 1 ", 29 in distance class " 2 ", and 14 in distance class " 3 " (Table 4).

This decreasing pattern of species abundance can also be found for other Carabidae species, as well as for some species of Elateridae. For instance, the abundance of species such as Calathus cinctus (Carabidae) and Agryotes aterrimus (Elateridae) dropped from 43 to 4 and from 20 to 5 , respectively, over the distance classes. On the other hand, given the fact that some taxa are more generalist than others, certain species showed a contrasting pattern with gains or losses in terms of specimen number along the same spatial gradient. For example, the abundance of Staphylinus olens (Staphylinidae) increased from the "1" to "2" distance class (from 8 to 16 specimens) and then decreased in class "3" (4 specimens). 

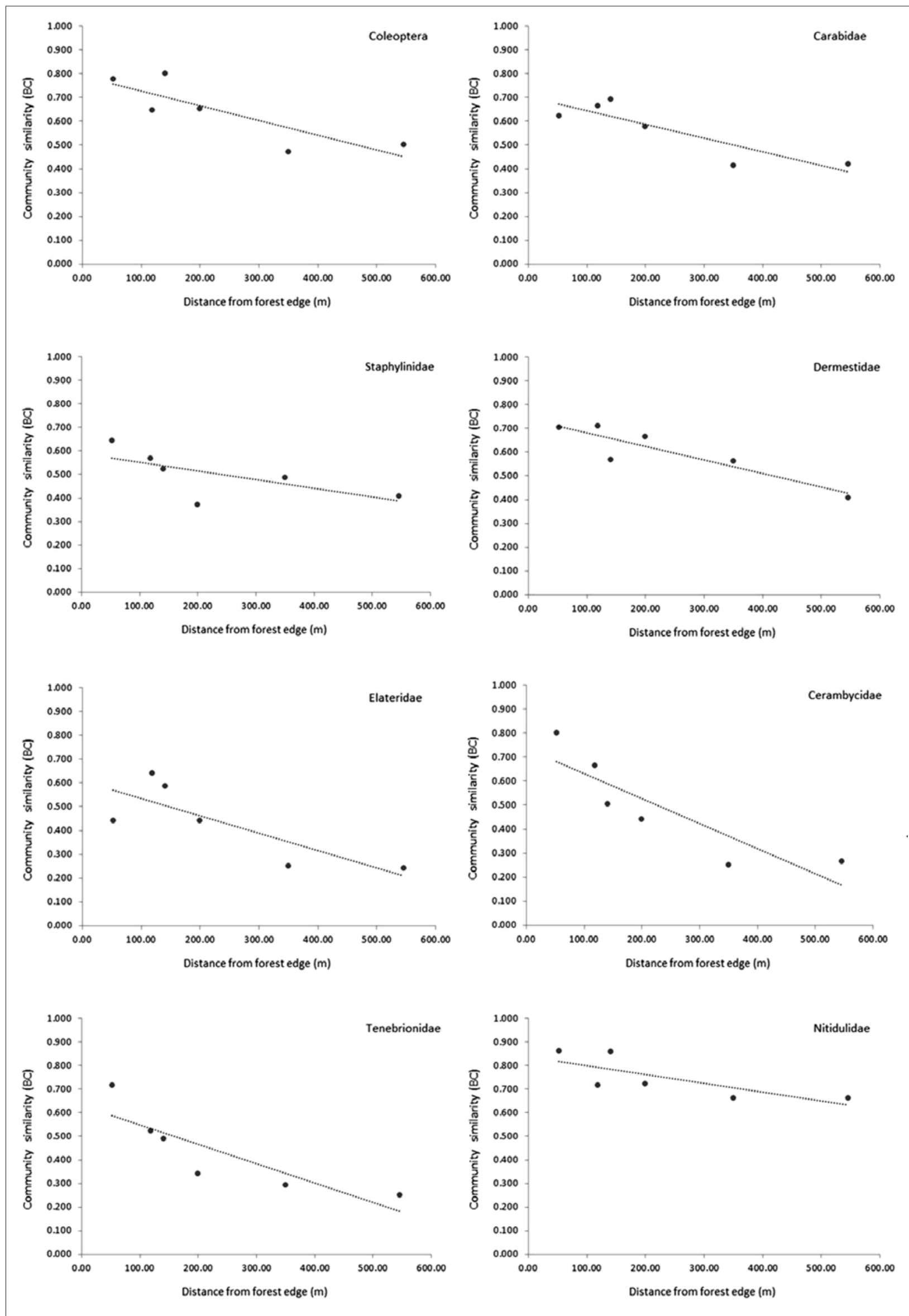

Fig. II - Linear regression models describing the relationship between beetle community similarity (Bray-Curtis index) and distance from the forest edge (D). 
Table 3 - Linear regression models explaining variation of community similarity as a function of distance from the nearest forest edge $(D)$.

\begin{tabular}{lcc}
\hline \hline Coleoptera & Regression model & $r^{2}$ \\
\hline Beetle community & $0.790-0.0006 * \mathrm{D}$ & 0.701 \\
Carabidae & $0.704-0.0006 * \mathrm{D}$ & 0.767 \\
Staphylinidae & $0.589-0.0004 * \mathrm{D}$ & 0.453 \\
Dermestidae & $0.738-0.0006 * \mathrm{D}$ & 0.815 \\
Elateridae & $0.606-0.0007 * \mathrm{D}$ & 0.641 \\
Cerambycidae & $0.734-0.001 * \mathrm{D}$ & 0.766 \\
Tenebrionidae & $0.630-0.0008 * \mathrm{D}$ & 0.734 \\
Nitidulidae & $0.838-0.0004 * \mathrm{D}$ & 0.578 \\
\hline
\end{tabular}

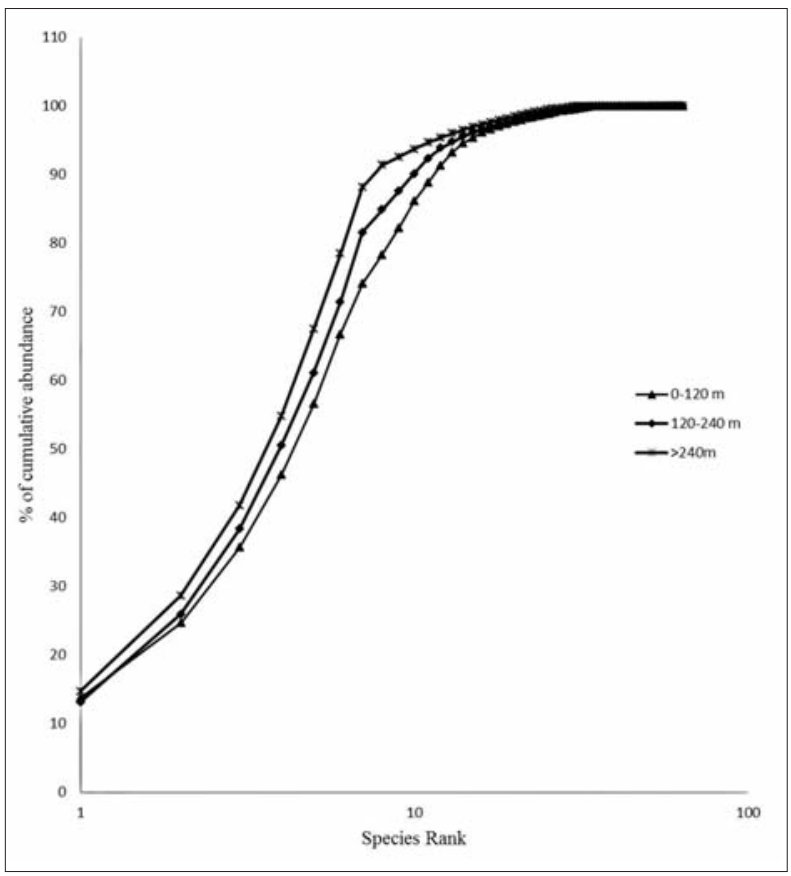

Fig. III - K-dominance curves for beetle species assemblage across three different distance classes from forest edge in a burnt area.

\section{DISCUSSION}

This study provides an integration of previous research conducted in Mediterranean forest ecosystems with the aim to evaluate the spatial and temporal response of insect community to fire (see EliA et al., 2012). Evidence has been provided on the relationship between wildfire occurrence and the mid-term response of beetle communities. Additional recent studies have provided similar evidence for other biogeographical regions (e.g., boreal and tropical) and support our decision to use epigeic or surface-dwelling fauna (e.g., ground beetles) as indicators of wildfire disturbance (YANOVSKY and KISELEV, 1996; McGeOCh, 1998; Orgeas and ANDERSEN, 2001; SIMILÄ et al., 2002; JoHANSSON et al., 2010). Families such as Carabidae (ground beetles), for example, are ideal taxa because they are sensitive to environmental change and can be easily caught in pitfall traps (NIELD, 1990; BUSE and Good, 1993; NiEMELÄ et al., 1996; SPENCE et al., 1996). Pit-fall traps are frequently employed in many areas of ecological research. This is perhaps due to the fact that other methods of trapping are more difficult and expensive to implement, particularly for surface-active invertebrates. Sometimes pitfall trapping is the only feasible method, as when population densities are low or when minimal impact methods are required for sensitive sites (SPENCE and NiEMELÄ, 1994; Melbourne, 1999).

Our findings indicate the existence of a negative relationship between beetle species composition and distance from the nearest forest edge in a burnt area. As the distance from the forest edge increases, the community similarity between burnt forest plots and control plots decreases, while the dominance of a few species increases. This result could be explained by the fact that the distance from the forest edge can be assumed as proxy of fire spread across the forest area and the subsequent changes in habitats. Fires affect the amount of sunlight reaching the forest floor and the diversity and spatial distribution of plant and animal communities (REED, 1997; BUDDLE et al., 2000; MORETTI et al., 2004). In addition, fire affects forest heterogeneity (BENGTSSON, 2002) by creating a mosaic of open spaces and edge areas; the mosaic is required for some insect species to engage in breeding, oviposition, foraging and nectaring (GRUNDEL et al., 1998).

By means of community similarity analyses (BC index) across the gradient from the forest interior to the forest edge and the burnt forest area, we found clear evidence that beetle communities are affected by wildfires still at 5 years after the fire event. Our results support the first hypothesis that the community composition and thus spatial turnover will vary across the gradient as a result of fire impacts. The similarity between forest edge and the interior forest (i.e., control plots), higher than that found between forest edge and area burned, suggests that the main habitat components did not differ significantly across this gradient, but provided suitable microclimatic conditions for forest species to move across the forest edge. For instance, BRIGIĆ et al. (2014) found that the carabid beetle assemblages near the forest edge in Croatian forests were more similar to those in the forest interior than those in the adjacent open area. Certainly, these patterns of similarity are likely to be strongly dependent on the specific taxa that we used as indicators. The life histories and dispersal mechanisms of beetles make them sensitive to changes in environmental conditions at relatively small scales (10s of meters) (LACASELLA et al., 2015). Indeed, if we were to consider other taxa they would respond differently depending on the habitats needed for their life cycle. For example, wild bees are often positively correlated with forest edge habitat, as they require canopy closure for nesting and open areas for foraging (DIAZFORERO et al., 2013; BoGUSCH et al., 2014). On the other hand, butterflies are primarily associated with open areas instead of the forest habitat (RICKETTS, 2001).

The k-dominance analysis suggests that the species assemblage in burnt forest locations is dominated by a few (generalist) species. There is a consensus that post-fire simplification in vegetation structure may cause the establishment of a few dominant (generalist) species (HERRANDO et al., 2003; SANTOS et al., 2014), which in turn can affect a diverse arrangement of beetle communities. Generalist species are favored in disturbed environments, while specialists prefer slowly changing environmental conditions (GILCHRIST, 1995; SULTAN, 2001; VAN BUSKIRK, 2002; RichmOND et al., 2005). Carabidae, which are more specialist, decrease in abundance and species richness as the distance from the forest edge increases, whereas abrupt habitat changes generated by disturbances could promote 
Table 4 - K-dominance and abundance values (in parentheses) of beetle species within the burnt area in the three different distance classes.

\begin{tabular}{|c|c|c|c|c|c|c|c|c|}
\hline \multicolumn{9}{|c|}{ Distance class } \\
\hline \multicolumn{3}{|l|}{$0-120 \mathrm{~m}$} & \multicolumn{3}{|c|}{$120-240 \mathrm{~m}$} & \multicolumn{3}{|c|}{$>240 \mathrm{~m}$} \\
\hline Epurea aestiva & 13.8 & (143) & Epurea pallescens & 13.2 & $(141)$ & Epurea unicolor & 14.7 & $(172)$ \\
\hline Carpophilus dimidatus & 24.7 & (113) & Carpophilus dimidatus & 25.9 & (137) & Epurea aestiva & 28.6 & $(163)$ \\
\hline Epurea pallescens & 35.7 & (113) & Epurea aestiva & 38.3 & (133) & Epurea pallescens & 41.8 & $(154)$ \\
\hline Carpophilus marginellus & 46.3 & $(110)$ & Epurea unicolor & 50.5 & $(130)$ & Pocadius ferrugineus & 54.8 & $(152)$ \\
\hline Urophorus humeralis & 56.6 & $(107)$ & Urophorus humeralis & 61.1 & (114) & Carpophilus marginellus & 67.4 & $(148)$ \\
\hline Epurea unicolor & 66.7 & $(104)$ & Pocadius ferrugineus & 71.5 & (111) & Carpophilus dimidatus & 78.5 & (129) \\
\hline Pocadius ferrugineus & 74.1 & (77) & Carpophilus marginellus & 81.5 & (108) & Urophorus humeralis & 88.1 & (113) \\
\hline Calathus cinctus & 78.3 & (43) & Soronia grisea & 84.9 & $(36)$ & Stenus sp. & 91.4 & $(38)$ \\
\hline Carabus coriaceus & 82.2 & $(41)$ & Carabus coriaceus & 87.6 & $(29)$ & Carabus coriaceus & 92.6 & (14) \\
\hline Stenus sp. & 86.2 & (41) & Stenus sp. & 90.1 & (27) & Soronia grisea & 93.7 & (13) \\
\hline Abax ater & 88.8 & (27) & Attagenus unicolor & 92.4 & (24) & Tachinus laticollis & 94.6 & (11) \\
\hline Soronia grisea & 91.3 & $(26)$ & Staphylinus olens & 93.8 & (16) & Attagenus unicolor & 95.4 & (9) \\
\hline Agriotes aterrimus & 93.2 & $(20)$ & Leistus spinibarbis & 94.8 & (10) & Cychrus caraboides & 96.0 & (7) \\
\hline Attagenus unicolor & 94.6 & (14) & Carabus violaceus & 95.5 & $(8)$ & Pterostichus nigrita & 96.5 & (6) \\
\hline Staphylinus olens & 95.4 & $(8)$ & Agriotes aterrimus & 96.1 & (6) & Agriotes aterrimus & 96.9 & (5) \\
\hline Tachyporus hypnorum & 96.1 & (8) & Tachinus laticollis & 96.5 & (5) & Calathus cinctus & 97.3 & (4) \\
\hline Harpalus luteicomis & 96.6 & (5) & Pterostichus melas & 96.9 & (4) & Potosia cuprea & 97.6 & (4) \\
\hline Carabus intricatus & 97.0 & (4) & Mastigus ruficornis & 97.2 & (3) & Staphylinus olens & 97.9 & (4) \\
\hline Carabus violaceus & 97.4 & (4) & Pedinus helopioides & 97.5 & (3) & Brachinus crepitans & 98.2 & (3) \\
\hline Cetonia aurata & 97.7 & (3) & Tentyria laevigata & 97.8 & (3) & Carabus glabratus & 98.5 & (3) \\
\hline Leistus spinibarbis & 98.0 & (3) & Abax ater & 97.9 & (2) & Cetonia aurata & 98.7 & (3) \\
\hline Pterostichus melas & 98.3 & (3) & Astrapaeus ulmi & 98.1 & (2) & Mastigus ruficornis & 99.0 & (3) \\
\hline Amara plebeja & 98.5 & (2) & Calathus cinctus & 98.3 & (2) & Colymbetes fuscus & 99.1 & (2) \\
\hline Cerambyx cerdo & 98.6 & (2) & Calathus fuscipes & 98.5 & (2) & Dorcus parallelepipedus & 99.3 & (2) \\
\hline Dermestes laniarius & 98.8 & (2) & Carabus intricatus & 98.7 & (2) & Elater ferrugineus & 99.5 & (2) \\
\hline Pissodes notatus & 99.0 & (2) & Harpalus luteicomis & 98.9 & (2) & Blaps mucronata & 99.6 & (1) \\
\hline Potosia cuprea & 99.2 & (2) & Pterostichus nigrita & 99.1 & (2) & Carabus violaceus & 99.7 & (1) \\
\hline Brachinus crepitans & 99.3 & (1) & Zabrus tenebrioides & 99.3 & (2) & Clytus arietis & 99.7 & (1) \\
\hline Calathus fuscipes & 99.4 & (1) & Cerambyx cerdo & 99.3 & (1) & Nebria brevicollis & 99.8 & (1) \\
\hline Cantharis livida & 99.5 & (1) & Harpalus rufipes & 99.4 & (1) & Pissodes notatus & 99.9 & (1) \\
\hline Clytus arietis & 99.6 & (1) & Melanotus villosus & 99.5 & (1) & Purpuricenus kaehleri & 100 & (1) \\
\hline Cychrus rostratus & 99.7 & (1) & Pachytychius hordei & 99.6 & (1) & Abax ater & 100 & $(0)$ \\
\hline Lagria hirta & 99.8 & (1) & Phosphuga atrata & 99.7 & (1) & Amara fulva & 100 & $(0)$ \\
\hline Pterostichus nigrita & 99.9 & (1) & Potosia cuprea & 99.8 & (1) & Amara plebeja & 100 & $(0)$ \\
\hline Silpha carinata & 100 & (1) & Purpuricenus kaehleri & 99.9 & (1) & Astrapaeus ulmi & 100 & $(0)$ \\
\hline Amara fulva & 100 & $(0)$ & Staphylinus caesareus & 100 & (1) & Blaps gibba & 100 & $(0)$ \\
\hline Astrapaeus ulmi & 100 & $(0)$ & Amara fulva & 100 & $(0)$ & Calathus fuscipes & 100 & $(0)$ \\
\hline Blaps gibba & 100 & $(0)$ & Amara plebeja & 100 & $(0)$ & Calosoma sycophanta & 100 & $(0)$ \\
\hline Blaps mucronata & 100 & $(0)$ & Blaps gibba & 100 & $(0)$ & Cantharis livida & 100 & $(0)$ \\
\hline Calosoma sycophanta & 100 & $(0)$ & Blaps mucronata & 100 & $(0)$ & Carabus intricatus & 100 & $(0)$ \\
\hline Carabus glabratus & 100 & $(0)$ & Brachinus crepitans & 100 & $(0)$ & Cerambyx cerdo & 100 & $(0)$ \\
\hline Colymbetes fuscus & 100 & $(0)$ & Calosoma sycophanta & 100 & $(0)$ & Cychrus italicus & 100 & $(0)$ \\
\hline Cychrus caraboides & 100 & $(0)$ & Cantharis livida & 100 & $(0)$ & Cychrus rostratus & 100 & $(0)$ \\
\hline Cychrus italicus & 100 & $(0)$ & Carabus glabratus & 100 & $(0)$ & Dermestes laniarius & 100 & $(0)$ \\
\hline Dermestes maculatus & 100 & $(0)$ & Cetonia aurata & 100 & $(0)$ & Dermestes maculatus & 100 & $(0)$ \\
\hline Dorcus parallelepipedus & 100 & $(0)$ & Clytus arietis & 100 & $(0)$ & Harpalus rufipes & 100 & $(0)$ \\
\hline Elater ferrugineus & 100 & $(0)$ & Colymbetes fuscus & 100 & $(0)$ & Harpalus luteicomis & 100 & $(0)$ \\
\hline Harpalus rufipes & 100 & $(0)$ & Cychrus caraboides & 100 & $(0)$ & Lacon punctatus & 100 & $(0)$ \\
\hline Lacon punctatus & 100 & $(0)$ & Cychrus italicus & 100 & $(0)$ & Lagria hirta & 100 & $(0)$ \\
\hline Leistus ferrugineus & 100 & $(0)$ & Cychrus rostratus & 100 & $(0)$ & Leistus ferrugineus & 100 & $(0)$ \\
\hline
\end{tabular}


Continued Table 4

\begin{tabular}{|c|c|c|c|c|c|c|c|c|}
\hline \multicolumn{9}{|c|}{ Distance class } \\
\hline \multicolumn{3}{|c|}{$0-120 \mathrm{~m}$} & \multicolumn{3}{|c|}{$120-240 \mathrm{~m}$} & \multicolumn{3}{|c|}{$>240 \mathrm{~m}$} \\
\hline Mastigus ruficornis & 100 & $(0)$ & Dermestes laniarius & 100 & $(0)$ & Leistus spinibarbis & 100 & $(0)$ \\
\hline Melanotus villosus & 100 & (0) & Dermestes maculatus & 100 & $(0)$ & Melanotus villosus & 100 & $(0)$ \\
\hline Nebria brevicollis & 100 & $(0)$ & Dorcus parallelepipedus & 100 & $(0)$ & Oedemra flavipes & 100 & $(0)$ \\
\hline Oedemra flavipes & 100 & (0) & Elater ferrugineus & 100 & $(0)$ & Pachytychius hordei & 100 & $(0)$ \\
\hline Pachytychius hordei & 100 & $(0)$ & Lacon punctatus & 100 & $(0)$ & Pedinus helopioides & 100 & (0) \\
\hline Pedinus helopioides & 100 & $(0)$ & Lagria hirta & 100 & $(0)$ & Phosphuga atrata & 100 & $(0)$ \\
\hline Phosphuga atrata & 100 & $(0)$ & Leistus ferrugineus & 100 & $(0)$ & Pterostichus melas & 100 & $(0)$ \\
\hline Purpuricenus kaehleri & 100 & (0) & Nebria brevicollis & 100 & (0) & Ropalopus clavipes & 100 & $(0)$ \\
\hline Ropalopus clavipes & 100 & $(0)$ & Oedemra flavipes & 100 & $(0)$ & Silpha carinata & 100 & $(0)$ \\
\hline Staphylinus caesareus & 100 & $(0)$ & Pissodes notatus & 100 & $(0)$ & Staphylinus caesareus & 100 & $(0)$ \\
\hline Tachinus laticollis & 100 & (0) & Ropalopus clavipes & 100 & (0) & Tachyporus hypnorum & 100 & $(0)$ \\
\hline Tentyria laevigata & 100 & $(0)$ & Silpha carinata & 100 & $(0)$ & Tentyria laevigata & 100 & $(0)$ \\
\hline Tenebrio molitor & 100 & $(0)$ & Tachyporus hypnorum & 100 & $(0)$ & Tenebrio molitor & 100 & $(0)$ \\
\hline Zabrus tenebrioides & 100 & $(0)$ & Tenebrio molitor & 100 & $(0)$ & Zabrus tenebrioides & 100 & $(0)$ \\
\hline TOTAL & & 1035 & TOTAL & & 1072 & TOTAL & & 1170 \\
\hline
\end{tabular}

more generalist species (FUTUYMA and MoReNo, 1988). Open spaces, potentially created by fires, support a greater number of generalist species as well as provide a suitable refuge and resources for species associated with such habitats. For example, Nitidulidae may be found in numerous diverse habitats feeding on flowers, fruits, sap, fungi, decaying and fermenting plant tissues or dead animal tissue (ARBOGAST, 2009). This finding is in line with other studies of plants (SPARKs et al., 1996; PETERKEN and FRANCIS, 1999; MULLEN et al., 2003) and other groups of arthropods (OXBROUGH et al., 2006; LARRIVÉE et al., 2008; BOSSART and OPUNI-FRIMPONG, 2009; LACASELLA et al., 2015).

The ability of a beetle community to recover from environmental change caused by wildfire (ISAAC et al,. 2009) has been linked to: (1) the diversity of responses at the ecosystem level (ELMQVIST at al., 2003); (2) the diversity and heterogeneity at the community level (BENGTSSON, 2002); and (3) particular functional traits (e.g., generalist species) at the species level (NORDEN et al., 2009).

Taken together, our analyses of the spatial patterns of beetle communities highlight an important point - they provide evidence on how varying taxa respond differently to fire as a consequence of their habitat requirements, modes of reproduction and dispersal mechanisms, all of which influence the way a given species, or family, responds to the spatial structure of a landscape. The positive impact of habitat heterogeneity on biodiversity is a wellknown and predictable rule in ecology (Tews et al., 2004). To preserve biodiversity, landscape management might provide mosaics of open and forest areas (Pons et al., 2003) maximizing the expansion of both open- and forestspecialist species and enhancing species turnover after new disturbances in burnt areas (BROTONS et al., 2005).

Finally, some specific limitations related to this study must be taken into consideration. We limited our field data collection to a single forest area (of $600 \mathrm{ha}$ ) because over the years this area has proved to be relatively unaffected by intensive grazing and hunting activities. Other forest areas have also been considered across the region, but field experiments could not be finalized due to significant damage to pit-falls traps. However, we plan to locate new field experiments in other forest areas affected by different wildfires intensity, because not all wildfires are the same and within a wildfire there is much variability in severity that could explain response. Furthermore, future research is needed to understand the effects of additional co-factors on beetle community composition, such as forest loss and fragmentation.

\section{CONCLUSIONS}

Adding to a growing list of researches on the importance wildfire impacts in preserving biodiversity in forest landscapes, this study suggested that five years after a fire, there is still an effect of fire on beetle community composition.

The majority of beetle communities surveyed reflect significant differences between burnt and unburnt sites as well as several differences in relation to the distance from the forest edge in a burnt area. The differences were probably driven by vegetation structure changes across the gradient from the burnt area to the forest interior, especially for those taxa with many specialist species in feeding and oviposition habitats.

Given the short term of our study, it would be, therefore, unwise to consider its conclusions as definitive, and further studies could investigate how beetle communities respond to forest recover. This will enable the prediction of how changes in habitats conditions within the gradient and as well as their managements, may influence assemblages of beetles.

Estimating the effects of wildfires on beetle communities is a prerequisite to establishing strategies and policies for counteracting biodiversity loss at the global, regional and national levels (CBD SECRETARIAT, 2001). The relationship between beetle assemblage similarity, the distance from forest edge, and the increased dominance at different distance classes in disturbed areas can help to achieve postfire management objectives. The main goal of forest managers, responsible for wildlife landscapes, is to preserve 
natural biodiversity by focusing on the conservation of endemic species. To this end, the maintenance of landscape heterogeneity of fire mosaics could be an appropriate management practice (BRADSTOCK et al., 2005; DRISCOLL et al., 2010; ELIA et al., 2012). In areas historically affected by wildfires, long-term studies should be conducted to: i) evaluate the effectiveness of post-fire management in terms of benefits for biodiversity; ii) recognize ecological mechanisms related to insect-fire interactions; and iii) identify reliable indicators (e.g., species) of post-fire processes.

\section{ACKNOWLEDGMENTS}

This study was carried out within: i) the FIRB 2012 project "Development of innovative models for multiscale monitoring of ecosystem service indicators in Mediterranean forests (MIMOSE)," funded by the Italian Ministry for Education, Universities and Research; ii) the INFO-BIO project "Influenza degli incendi boschivi sulla Biodiversità pugliese" funded by the Cassa Di Risparmio di Puglia Foundation. Further, the authors also wish to thank Thomas A. Spies for contributing to the review of this work.

\section{REFERENCES}

Arbogast R.T., Torto B., Willms S., Teal PEA., 2009 Trophic Habits of Aethina tumida Coleoptera: Nitidulidae: Their Adaptive Significance and Relevance to Dispersal. - Environ. Entomol., 38 (3): 561-568.

Bengtsson J., 2002 - Disturbance and resilience in soil animal communities. - Eur. J. Soil Biol., 38: 119-125.

Bogusch P., BlažEj L., TrÝZna M., Heneberg P., 2015 Forgotten role of fires in Central European forests: critical importance of early post-fire successional stages for bees and wasps Hymenoptera: Aculeata. - Eur. J. For. Res. 134 (1): 153-166.

Bradstock R.A., Bedward M., Gill A.M., Cohn J.S., 2005 - Which mosaic? A landscape ecological approach for evaluating interactions between fire regimes, habitat and animals. Wild. Res., 32: 409-423.

Brotons L., Pons P., Herrando S., 2005 - Colonisation of dynamic Mediterranean landscapes: where do birds come from after fire? - J Biogeogr., 32: 789-798.

Buddle C.M., Spence J.R., Langor D.W., 2000 Succession of boreal forest spider assemblages following wildfire and harvesting. - Ecography., 23: 424-436.

Buse A., Good J.E.G, 1993 - The e ects of conifer forest design and management on abundance and diversity of rove beetles (Coleoptera: Staphylinidae): implications for conservation. - Biological Conservation 64 (1): 67-76.

CBD SECRETARIAT , 2001 - Handbook of the convention on biological diversity, 3rd edn Earthscan, London.

DipPENAAR-SCHOEMAN A.S., 2002 - Baboon and trapdoor spiders of Southern Africa: an identification manual Plant Protection Research Institute Handbook No 13. Agricultural Research Council, Pretoria.

Driscoll D.A., Lindenmayer D.B., BennetT A.F., Bode M., BRADSTOCK R.A. et al., 2010 - Fire management for biodiversity conservation: Key research questions and our capacity to answer them. - Biol. Conserv., 143: 19281939

Elia M., Lafortezza R., Tarasco E., Colangelo G., SANESI G., 2012 - The spatial and temporal response of fire on insect abundance in Mediterranean forest ecosystems. - For. Ecol. Manage., 263: 262-267.
Elia M., Lafortezza R., Colangelo G., SANesi G., 2014 A streamlined approach for the spatial allocation of fuel removals in wildland-urban interfaces. - Landscape Ecol., 29: 1771-1784.

Elia M., LAFORTEZza R., LOVREgLIO R., SANEsi G., 2015 Developing Custom Fire Behavior Fuel Models for Mediterranean Wildland-Urban Interfaces in Southern Italy. - Environ. Mnage., 56 (3): 754-764.

Elia M., Lovreglio R., Ranieri N.A., Sanesi G., LAFORTEZZA R., 2016 - Cost-effectiveness of fuel removals in Mediterranean wildland-urban interfaces threatened by wildfires. - Forests, 7, 149.

Elmqvist T., Folke C., Nystrom M., Peterson G., Bengtsson J., et al., 2003 - Response diversity, ecosystem change, and resilience. - Front. Ecol. Environ, 1: 488-494.

Futuyma D.J., Moreno G., 1988 - The evolution of ecological specialization. - Annual Rev. Ecol., System 19: 207-233.

Garcia-Tejero S., Taboada Á., TÁrrega R., Salgado J., MARcos E., 2013 - Differential responses of ecosystem components to a low-intensity fire in a Mediterranean forest: a three-year case study. - Community Ecology 14 (1): $110-120$.

García-Tejero S., Taboada Á., TÁrrega R., SAlgado J.M. 2013 - Land use changes and ground dwelling beetle conservation in extensive grazing dehesa systems of north-west Spain. Biol. - Conserv., 161: 58-66.

GRundel R., PaVlovic N.B., SulzMAN C.L., 1998 - Habitat use by the endangered Karner blue butterfly in oak woodlands: the influence of canopy cover. - Biol. Conserv., 85: 47-53

Holliday N.J., 1991 - Carabid beetles (Coleoptera: Carabidae) from a burned spruce forest Picea spp. - Can. Ent., 116: 919-922.

IsAaC J.L., VANDERWAL J., Johnson C.N., Williams S.E. 2009 - Resistance and resilience: quantifying relative extinction risk in a diverse assemblage of Australian tropical rainforest vertebrates. - Divers. Distrib. 15: 280288.

Johansson T., Huältén J., Stenbacka F., Dynesius M., 2010 - Responses of eight boreal flat bug Heteroptera: Aradidae species to clear-cutting and forest fire. - J. Insect Conserv., 14 (1): 3-9

Johansson T., Andersson J., HuÄltén J., Dynesius M., ECKE F., 2011 - Short-term responses of beetle assemblages to wildfire in a region with more than 100 years of fire suppression. - Insect Conserv. Divers., 4 (2): 142-151.

Koivula M., Spence J.R., 2006 - Effects of post-fire salvage logging on boreal mixed wood ground beetle assemblages (Coleoptera, Carabidae). - For. Ecol. Manage., 236: 102-112.

Lafortezza R., CoOmes D.A., Kapos V., Ewers R.M., 2010 - Assessing the impacts of fragmentation on plant communities in New Zealand: scaling from survey plots to landscapes. - Global Ecol. Biogeogr., 19 (5): 741-754.

LAFortezza R., TANentZAP A.J., Elia M., John R., SANESI G., CHEN J., 2015 - Prioritizing fuel management in urban interfaces threatened by wildfires. - Ecol. Indic., 48: 342-347.

LARSEN K.J., WiLliams JB., 1999 - Influence of fire and trapping effort on ground beetles in a reconstructed tallgrass prairie Prairie. - Nat. 31: 75-86.

MAGURRAN A.E., 2004 - Measuring biological biodiversity. Blackwell Science Ltd, Oxford

McGeOch M.A., 1998 - The selection, testing and 
application of terrestrial insects as bioindicators. - Biol. Rev., 73: 181-201.

Moretti M., Obrist M.K., Duelli P., 2004 - Arthropod biodiversity after forest fires: winners and losers in the winter fire regime of the southern Alps. - Ecography 27: 173-186.

NIELD C.E., 1990 - Is it possible to age woodlands on the basis of their carabid beetle diversity? -The Entomologist 109: 137-145.

Niemelä J., 1996 - Invertebrates and boreal forest management. - Conserv. Biol., 11 (3): 601-610.

Norden N., Chazdon R.L., ChaO A., Jiang Y-H., VI'LCHEZ-AlVARADO B., 2009 - Resilience of tropical rain forests: tree community reassembly in secondary forests. - Ecol. Let., 12: 385-394.

Orgeas J., ANDERSEN A.N., 2001 - Fire and biodiversity: responses of grass-layer beetles to experimental fire regimes in an Australian tropical savanna. - J. Appl. Ecol., 38: 49-62.

PARSONS C.T., 1943 - A revision of the Nearctic Nitidulidae (Coleoptera). - Bull. Mus. Comp. Zool. Harv. Univ., 92:121-278.

Pons P., Lambert B., Rigolot E., Prodon R., 2003 - The effects of grassland management using fire on habitat occupancy and conservation of birds in a mosaic landscape. Biodiv. Conserv., 12: 1843-1860.

PRYK J.S., SAMWAYS M.J., 2012 - Importance of using many taxa and having adequate controls for monitoring impacts of fires for arthropod conservation. - J. Insect Conserv., 16: 177-185.

RAINIO J., Nimelä J., 2004 - Ground beetles (Coleoptera: Carabidae) as bioindicators. - Biodivers. Conserv., 12: 487-506.

REED C.C., 1997 - Response of prairie insects and other arthropods to prescription burns. - Nat. Areas J., 17: 380385.

RICKLEFS R.E., 1977 - Environmental heterogeneity and plant species diversity: a hypothesis. - Am. Nat., 111: 376-381.
Saint-Germain M., Larrivé M., Drapeau P., Fahrig L., BUDDLE C., 2005 - Short-term response of ground beetles (Coleoptera: Carabidae) to fire and logging in a sprucedominated boreal landscape. - Forest Ecol. Manag., 212: 118-126.

Santos X., Mateos E., Bros V., Brotons L., De Mas E., et al., 2014 - Is Response to Fire Influenced by Dietary Specialization and Mobility? A Comparative Study with Multiple Animal Assemblages. - PLoS ONE 9 (2): e88224 doi:101371/journalpone0088224.

SIMILÄ M., et al., 2002 - Conservation of beetles in boreal pine forests: the effects of forest age and naturalness on species assemblages. - Biol. Conserv., 106:19-27.

Spence J.R., Niemela J.K., 1994 - Sampling carabid assemblages with pitfall traps: the method and the madness. - Canadian Entomologist 126: 881-894.

Tews J., Brose U., Grimm V., Tielbörger K., WichmanN M.C., et al., 2004 - Animal species diversity driven by habitat heterogeneity/diversity: the importance of keystone structures. - J Biogeogr. 31: 79-92.

Uys C., HAMER M., SLOTOW R., 2006 - Effect of burn area on invertebrate recolonization in grasslands in the Drakensberg, South Africa. - Afr. Zool., 41: 31-65.

Villa-Castillo J., Wagner M.R., 2002 - Ground beetle (Coleoptera:Carabidae) species assemblage as indicator of forest condition in northern Arizona ponderosa pine forests. - Environ. Entomol., 31: 242-252.

Villani M.G., Allee L.L., Díaz A., RobBins P.S., 1999 Adaptive strategies of edaphic arthropods. - Annu. Rev. Entomol., 44: 233-256.

YANOVSKy V.M., KiseleV V.V., 1996 - Response of the endemic insect fauna to fire damage. In: Goldammer J.G. (Eds), Fire in ecosystems of boreal Eurasia Kluwer. pp 409-413. 